\title{
A MODEL OF COMMUNICATIVE TEACHING AND LEARNING OF ENGLISH VOCABULARY THROUGH INTERACTIVE ACTIVITIES
}

\author{
Sri Endang Kusmaryati \\ Universitas Muria Kudus, Indonesia
}

\begin{abstract}
Teaching English vocabulary is very important, and it is more than just presenting and introducing new vocabulary to the students. Knowing words is not only memorizing them, but the students need to understand the meaning of the word in context and how the words are used. This can be achieved through correct vocabulary instruction which should involve vocabulary selection, word knowledge and techniques. This article aims to describe how to design a model of communivative teaching and learning of English vocabulary through interactive activities.
\end{abstract}

Key words: design, topic-based, ESP materials, Vocational School

\section{INTRODUCTION}

People use language to communicate with others in their lives. As a means of communication, language has a central role in the development of intellectual, social, and emotional to support students in the process of teaching and learning. It also supports the success of the study in all fields. Language learning is expected to help students know themselves, their culture, and the culture of others. In addition, learning language also helps them to express ideas and feelings, participate in the community, even find and use their critical, analytical and imaginative abilities.

Language is a means to communicate in spoken and written. Communicate is to understand and express information, thoughts, feelings, and develop science, technology, and culture. The ability to communicate means the ability to understand and produce spoken texts and writing realized in the four language skills, namely listening, speaking, reading and writing. The Four skills are used to respond or create discourse in social lives.Therefore, subjects of English are directed to develop the four skillsto make graduates able to communicate in English in spoken and written.

English as a foreign language has an important role in Indonesia and it is taught from elementary schools to postgraduate programs of university, even in some kindergartens, English is also taught as a compulsary subject, local content or extra curricular. This condition certainly needs skillful teachers who are able to teach English effectively and and make the students enjoyable in joining the class.

In fact the English profeciency of the senior high schools students in Indonesia tend to be in a very low level. It means the students who have been studying English for more than six years can not use English communicatively both in spoken and written. Based on a personal interview with some English teachers in Kudus, the students tend to study English for getting the passing grade of the English subject. Besides the English subject is still taught structurally. The 
students study more about the grammar, so they are still dificult to use English in communication. They do not feel confident frequently to communicate by using English, even they feel afraid to make mistakes in using English communicatively. The English teachers also said that the students are not really intersested in studying English. According to them, English is a difficult subject to master. Besides, from the personal conversation with some students, they said that the English teachers usually use the same technique in the process of teaching and learning. The score of English achievements tend to be under passing grade. It is also found that in the process of teaching and learning, the teachers reraly use English in the classroom, they tend to use Indonesian in interacting with the students. Sometimes the teachers speak English in the classroom, but they tend to use the same expression, like 'Good morning', 'How are you', 'Who is absent today?', 'Thank you', dan 'Good bye'.

Teaching English needs to set standards of English competence for the students to organize the subjects of English. The competece of the studentsshould beappropriateand useful in order to prepare them to learn English atthe higher level. Teaching English is intended to develop language skills used to accompany the activities in the students' life. The purpose of teaching English aims to make the students have communicative competence and also have awareness of the importance of English in enhancing the nation's competitivenessin a global society.

Teaching English vocabulary is very important, and it is more than just presenting and introducing new vocabulary to the students. Knowing words is not only memorizing them, but the students need tounderstand the meaning of the word in context and how the words are used. This can be achieved through correct vocabulary instruction which should involve vocabulary selection, word knowledge and techniques. The needs of prospective teachers in mastering English both spoken and written, and the ability to teach using English as the language of instruction in the teaching and learning process in the classroom is very important. They also need the skills to teach English effectively to make the students enjoyable have self-confidence to use English communcatively.

Deciding an interesting method for students is also an English teachers' job to do. As mentioned previously the students study English mostly to have communicative competence. They are expected to be able to have productive and receptive communicative competence. The students need to have the relevant English communicative competence appropriately both in spoken and written to continue their study in higher level. A model of teaching English should be designed to make the students have communicative competence. In this paper the writer tries to design a model of teaching and learning of English vocabulary through interactive activities.

\section{LITERATURE REVIEW}

\section{Vocabulary as a Component of language Teaching}

Vocabulary is a very important component of language needed by everyone to understand the meaning of words and help them express the idea. McCarthy 
(1990) says: "The single, biggest component of any component of any language course is vocabulary. No matter how well the students learn grammar, no matter how successfully the sounds of L2 are mastered, without words to express a wide range of meanings, communication in an L2 just cannot happen in any meaningful way. And yet vocabulary often seems to be the least system and yet vocabulary often seems to be the least systematized and the least well catered for all the aspects of the least well catered for all the aspects of learning a foreign language".

The purpose of the mastery of vocabulary is to make the students have a good language profeciency in language skills. Vocabulary is the collections of words everyone knows. Mastering vocabulary is vey important and should be developed by the learners. Without having enough vocabularies, it would be difficult to convey ideas or opinions. Therefore developing new vocabularies everyday for the students is very important, especially in acquisition a foreign language.

Richards and Renandya (2002: 255) describes: "Vocabulary is a core component of language proficiency and provides much of the basis for how well learners speak, listen, read, and write. Without an extensive vocabulary and strategies for acquiring new vocabulary, learners often achieve less than their potential and may be discouraged from making use of language learning opportunities around them, such as listening radio, listening to native speakers, using language in different context, reading, or watching television".

"Mastering vocabulary means knowing words involving knowing the form of a word (its spelling, sound, and word parts), knowing the meaning of a word (linking its form and meaning), knowing a concept for the word and what it can refer to, and knowing what other words of related meaning it can be associated with, and knowing how a word is used (the grammar of word including part of speech and the sentence patterns it fits into, collocates of the words, and whether the word is formal or informal, polite or rude, used mainly by children and so on, or has no restrictions on its use)" (Nation in Hinkel. 2005: 583-584).

Knowing words means knowing vocabulary as a list or collection of words or of words and phrases usually alphabetically arranged and explained or defined. Vocabulary is also a sum or stock of words employed by a language, group, individual, or work or in a field of knowledge (Merriam-Webster). Word is a smallest meaningful units of sounds. Thornbury (2002:12) explains about words as the following.

- Words have different functions, some carrying mainly grammatical meaning, while others bear imformational load.

- The same words can have a variety of forms

- Word can be added to, or combined, to form new words

- Words can group together to form units that behave as if they were single words.

- Many words commonly co-accur with other words.

- Words may have a variety of overlapping meanings

- Different words may share similar meanings of may have apposite meanings.

- Some words can be defined in terms of their relationship with other words 
- Words can have the same or similar meaning but be used in different situations and from different effects.

This means words are very complicated. They have variety of functions, variety of meanings, even variety of forms. Words also can be used in different situation and have different effects.

As a list of words, vocabulary could be mastered receptively and productively. Nation (2001) eplains the two distinctions of receptive and productive mastery of vocabulary. Mastery of receptive vocabulary, for example the word 'underdeveloped', means:

- being able to recognise the word when it is heard

- being familiar with its written form so that it is recognised when it is met in reading

- recognising that it is made up ofthe parts under-,-develop- and-ed and being able to relate these parts to its meaning

- knowing that underdeveloped signals a particular meaning

- knowing what the word means in the particular context in which it has just occured

- knowing the concept behind the word which will allow undestanding in a veriaty of contexts

- knowing that there are related words like overdeveloped, backward, and challenged

- being able to recognise the underdeveloped has been used correctly in the sentence in which it occurs

- being able to recognise that words such as territories and areas are typical collocations

- knowing that underdeveloped is an uncommon word and is not a pejorative word

Receptive vocabulary mastery does not only mean knowing the words generally, but also recognising and knowing their forms, parts, structures, meanings, uses in context and the rests. Besides Nation (2001:28) also describes the mastery of productive vocabulary for example the word 'underdeveloped' as the following.

- being able to say it with correct pronunciation including the stress

- being able to write it with correct spelling

- being able to construct it using the right word parts in their appropriate forms

- being able to produce the word to express the meaning.

- being able to produce the word in different contexts to express the range of the meaning

- being able to produce synonyms an opposites of the word

- being able to use the word correctly in an original sentence

- being able to produce the words commonly occur with it

- being able to decide to use or not to use the word to suit the degree of formaliy of the situation. 
It is quite clear that productive mastery of vocabulary does not only mean being able to use the words in communication, but also produce the words in different contexts, say the words correctly, write in correct spellings, know the synonyms and antonyms and the rests.

In line with Nation, Finnochiaro (1974) classifies the vocabulary into two terms: active and pasive vocabulary. Active vocabulary or productive vocabulary refers to the words the student understands, can pronounce correctly and use them constructively in speaking and writing and passive vocabulary or receptive vocabulary refers to the words in which the students can recognize and understand while they are reading or listening to someone speaking.

\section{Teaching English Vocabulary}

Teaching English vocabulary is as important as teaching pronunciation and grammar. Teaching English vocabulary plays an important role in language acquisition because by mastering vocabulary, it will help the students to master the four languagge skills: Listening, speaking, reading, and writing. Richard (2002:255) expalines: "Vocabulary is the core component of language proficiency and provides much of the basis for how well learners listen, speak, read, and write".

Before deciding to teach vocabulary, a teacher should consider the high and low frequency words of language as Nation (2001:16) says: "The high fequency words of language are clearly so important that considerable time should be spent on them by teachers and learners. High frequency words of language means the words that cover a very large proportion of the running words in spoken and written texts and occur in all kinds of uses of the language" (Nation. 2001:13).

Teaching vocabulary is a very important field, and it is more than just presenting and introducing new vocabulary to the learners. Knowing words is not filling papers with new words and memorizing them. What students need to understand is the word meaning in context and how words are used. This can be achieved through correct vocabulary instruction which should involve vocabulary selection, word knowledge and techniques.The general aim of teaching vocabulary is to involve the students in a more autonomous learning, rather than simply having them presented with word lists selected by the teacher or syllabus.In learning English as a foreign language, a learner is forced to be autonomous and independent and make conscious effort to learn vocabulary outside the classroom,because the exposure to the target language is limited in class. So teachers cannot rely on their students 'picking up' lexical items. This makes explicit vocabulary teaching necessary. However, vocabulary is notoriously difficult if not impossible to teach because of the complexity of its linguistic, semantic and psycho-cognitive aspects.

The teacher should teach vocabulary with the ways of presenting new vocabulary variously. In order to improve the efficiency of vocabulary learning, students should be encouraged to make use of learning strategies, self-initiated independent learning strategies. The strategies involve planned, active and motivated learning and exposure to language outside the classroom. Hunt and 
Beglar in Richards and Renandya (2002) explain the three approaches for vocabulary development to vocabulary instruction and learning, they are: incidental learning, explisit instruction, and independent strategy development. The incidental learning of vocabualry requires that teachers provide opportunities for extensive reading and listening. Explicit instruction involves diagnosing the words learners need to know, presenting words for the first time, elaborating word knowledge, and developing fluency with known words, independent strategy development involves practicing guessing from context and training learners to use dictionaries. Meanwhile Schmitt and McCharty (1997) divide the vocabulary learning strategies into four groups, namely:

1. Discovery Strategies. In this stage, when learners do not know the words, they must discover their meaning by guessing from structural knowledge of the language.

2. Social Strategies. A second way to discover new meaning employs the social strategy of asking someone who knows. Teachers are often in this position. They can be asked to help in a variety of ways. They can be asked to help in a variety ways: giving the translation, giving a synonym, definition, and paraphrase.

3. Memory Strategies. Most memory strategies involve relating the word to be retained with some previously learners' knowledge, using some form of imagery or grouping. The strategies used in this stage are pictures, related words, unrelated words, grouping, etc.

4. Cognitive strategies. Language strategies in this taxonomy are similar to memory strategies, but are not focused specially on manipulative mental processing; they include sorting, classifying, comparing, predicating, repeating and use mechanical means to study vocabulary.

In the process of teaching and learning, a teacher can also use some interesting and enjoyable ways to improve the student mastery of vocabulary as some examples mentioned by Tornbury (2002:33).

- The teacher reads words from the list in a random order. Learners show they can match the sounds with the written forms by tickimg the ones they hear. They can then do this with each other in pairs.

- Learners cover the L1 translation (if they have a bilingual list). The teacher gives translation and learners tick the English equivalents.

- Both the preceding activities can be turned into form of Bingo. Ask learners each to write down, say the words. Read out the words from the master list in random order, or read out their L1 translation. Alternatively if the words can be illustrated, show pictures of the words. Learners tick out each word as it occurs. The first learner to have tucked all the words shouts out Bingo.

- From a random list of words, ask learners to make connections between words and explain them to their classmates. The more connections the better, no matter how far-fetched. 
- Students construct a story from the list. They can do this by choosing the words from a list, and working them into a narrative, or they take turns to make sentence that includes the next word in the list so as to continue the story.

- Ask learners to make their own list from the words that come up in the lesson and to bring their lists to class for the next lesson. At the beginning of the following lesson. Pair students up to test each other on their words list.

- Learners can also make lists of words that have appearred in the previous units at the course book, and test each other by, for example, using ' How do you say ... in English? or What's the English from.....? or they can prepare gapped sentences to be completed by words from their lists.

Beside the approaches and strategies of teaching, materials of teaching and learning vocabulary must be designed appropriately for the students. Tomlinson and Masuhara (2004: 2) say that teaching materials is important for the teacher to prepare, based on a result of reflection and other teachers' practice because:

1. Language learners only successed if learning is a positive, relaxed and enjoyable experience.

2. Language teachers teach more successfully if they can gain gain some enjoyable themselves from the materials they are using.

3. Learners only learn what they really need and want to learn.

4. Materials should help learners to connect the learning experience in the classroom to their own lives outside it.

5. Materials should engage the emotions of the learner. in the classroom to their own lives outside it.

6. Materials should engage the emotions of the learner.

The teaching materialscan help students in two broad areas: First, they need to present and practice in natural contexts the vocabulary that is frequent, current, and appropriate to learners' needs. Second, materials should help students become better learners of vocabulary by teaching different techniques and strategies they can use to continue learning outside the classroom. The variety of vocabulary types to be learned, including single words, phrases, collocations, and strategic vocabulary, as well as grammatical patterning, idioms, and fixed expressions. Richards (1976) and Nation in McCarten (2007: 18) list that the different things learners need to know about a word before it can be said that they have learned it. These include:

- The meaning(s) of the word

- Its spoken and written forms

- What "word parts" it has (e.g., any prefix, suffix, and "root" form)

- Its grammatical behavior (e.g., its word class, typical grammatical patterns it occurs in)

- Its collocations

- Its register

- What associations it has (e.g., words that are similar or opposite in meaning)

- What connotations it has 
- Its frequency

The materials of teaching vocabulary should be appropriate to the standard competencies, the basic competencies and the indicators of each language skill. In order to achieve the purpose of teaching, the teacher must choose the suitable materials relate to their students need. The materials of teaching vocabulary based on Nation (1976) opinion must include the meaning of the words, the parts of the words, the words classes, the collocation and register, synonyms and antonyms, frequency, and also the conotations of the words.

\section{Communicative Language Teaching}

Communicative language teaching involves the process of teaching and learning in the classroom. Teaching is showing and helping someone to learn to do something, giving instruction, guiding in the study of something, providing with knowledge, causing to know or understand. Teaching is guiding and facilitating learning, enabling the learner to learn, setting the condition for learning. The understanding of how the learner learns will determine the philosophy of education, teaching style, approach, methods, and classroom techniques.(Brown, 2000:7). Learning is a process of acquiring and getting knowledge, moreover Brown (2000:7-8) defines about learning in detail as follows:

1. Learning is acquisition

2. Learning is retention of information or skill

3. Retention implies storage system, memory, cognitive organization

4. Learning involve active, conscious focus on and acting upon events outside or inside the organism.

5. Learning is relatively permanent but subject to forget

6. Learning involves some form of practice, perhaps reinforce practice

7. Learning is a change in behavior.

Teaching is a process of education which can be defined as a planned and conscious effort to bring about an atmosphere of teaching and learning process to develop potential learners actively and for them to have a religious, spiritual power of self-control, personality, intelligence, spoken, as well as the necessary skills for themselves, the community, the nation and the State (Undang Undang No.20. 2003. in SISDIKNAS).

Education is also defined to create the atmosphere of teaching and learning process to make learners actively develope their potential abilities. Besides, education is defined as the development of humanist, that seeks to develop all learners potential. In this case there are two major activities in education: a) creating an atmosphere of learning, and b) developing the learning process. Creating the learning atmosphere means an effort to create a learning environment included: a) the physical environment, such as: school buildings, classrooms, library, principal, teacher's room, the school garden and other physical environment; and b) socio-psychological environment (climate and cultural learning/academic), such as: commitment, teamwork, expectations of 
achievement, creativity, tolerance, happiness and comfort aspects socio-emotional or other, which allows the learners do the learning activities. Both the physical and socio-psychological environments are formed in order that learners can actively develop all their potential. It seems clear that the teacher's skills in managing the class became very important. The role of the teacher is a facilitator of learning for students.

The learning process emphasizes more on efforts on how to achieve the learning objectives or competencies of students. The teachers are required to be able to manage learning, which includes planning, implementation, and assessment of learning. Here, the teachers are acting as agents of learning, where teachers act as a planner, organizer and a learning evaluator. Just as in realizing the atmosphere of learning, the learning process was designed to make the learners should be able to develop actively all their potential, with the emphasis on student centered learning in active learning strategies.

The purpose of teaching Englishgenerally is for the students to be able to use the language communicatively, both in spoken and written. The essence of communicative language teaching is the engagement of learners in communication to allow them to develop their comunicative competence (Savignon in Hinkel, 2005: 635). While Richards (2006:2-3) says: "communicative language teaching (CLT) is a set of principles about the goal of language teaching, how learners learn a language, the kinds of classroom activities that best facilitate learning, and the roles of teachers and learners in the classroom". The goals of language teaching is teaching communicative competence, applying grammatical competence in communinication. Grammatical competence refers to the knowledge we have of a language that accounts for our ability to produce sentences in a language. It is the mastery of the rules of sentence formation in a language. While communicative competence is the use of the language for meaningful communication. Communicative competence includes aspects of knowledge about:

1. Knowing how to use language for a range of different purposes and functions.

2. Knowing how to vary the use of language according to the setting and participant (e.g. knowing when to use formal and informal speech or when to use language appropriately for written as opposed to spoken communication).

3. Knowing how to produce and understand different types of texts (e.g. narrative, descriptives, repots, interviews, conversations).

4. Knowing how to maintain communicantion despite having limitations in one's language knowledge (e.g. through using different kinds of communication strategies).

Communicative competence includes not only knowledge of the language, but also includes the ability to use the language in accordance with the sociocultural context. Communicative competence not only provides knowledge the rules of grammar, but also contains the knowledge of whether or not an utterance should be used according to the status of the speaker and the listener, space and time of the conversation, degrees of formality, the medium used, the subject, and the realm circumstances surrounding the conversation. This view suggests that 
socio-cultural factors that are the context of the use of language is a matter that needs to be known by the language learners so that they can communicate properly in areal situation.

Language learning is affected by the social and sociolinguistic contexts as explained by Mckay and Rubdy in Long and Doughty (2009) that the social context of language learning means how language teaching contexts are affected by the learners social, political, and educational setting in which the teaching carries out. Meanwhile the sociolinguistic context of language learning means how the linguistic features of interaction, both inside and outside of the classroom, are affected by the social context in which the interaction carries out.

From the description above, it is clear that teaching English communicatively is not only teaching about language components, but the English teacher must also consider the education as a process of education, language as a means of communication, English as a foreign language and also about sociocultural aspect in teaching English. Language competence involves the organizational competence and pragmatic competence. To achieve communicative competence Madya (2013) explaines that the activities in the classroom can be devided into pre-communication and communication. Pre-communication activities focus on relevant language forms and their function. These activities focus to help students to get knowledge about the grammar, spelling, pronunciation, and vocabulary to develop skills to use them in level of sentences. While communicative competence activities focus on the use of the forms and functions of language they have learned in pre-communication to achieve communicative functions.

\section{Interactive Activities in the Process of Teaching and Learning}

Based on constructivism theory of learning (Brown, 2000), a learner is an information constructor. Learning is an active, contextualized process of constructing knowledge rather than acquiring them. Knowledge is constructed based on personal experience. Each person has a different interpretation and construction of knowledge process. The role of teachers is very important within the constructivism learning theory. Instead of giving a lecture the teachers in this theory function as facilitators whose role is to aid the student when it comes to their own understanding. This takes away focus from the teacher and lecture and puts it upon the student and their learning.

Classroom as a place of teaching-learning interaction is often called as an artificial environment for teaching, learning, and using a foreign language. However, the classroom is also a real social context in which learners and teacher enter into real social relationships with each other. The teaching and learning process is a set of interaction between teacher and students. The value and quality of interaction in the teaching learning process establish a learning achievement.

Interaction is the collaborative exchange of thoughts, feelings, or ideas between two or more people, resulting in a reciprocal effect on each other. Through interaction, students can increase their language store as they listen to or read authentic linguistic material, or even the output of their fellow students in discussions, joint problem-solving tasks, dialogue journals. Interaction can use all 
they posses of the language - all they have learned or casually absorbed - in real life exchange (Rivers in Brown. 2000)

It is the responsibility of the teacher to create a learning atmosphere inside the classroom. It is through these interactive sessions that the teacher can extract responses from learners and motivate them to come out with new ideas related to the topic. The teachercan help the learners to construct an innovative learning product through group discussions, story telling, role play and many more. The teacher can act as a planner who plans out the best of the modules of interaction that would be effective to invite the learners in classroom interaction.In designing classroom activities Grave (2000:152-155) gives some suggestions to consider as the following.

1. Activities should draw on what students know (their experience, their current situation) and be relevant to them.

2. Activities should focus on students' outside of class needs, if approppriate.

3. Activities should build students' confidence

4. Activities should allow students to problem solve, discover, analyze.

5. Activities should help students develop specific skills and strategies

6. Activities should help students develop specific language and skills, they need for authentic communication

7. Activities should integrate the four skills of speaking, listening, reading, and writing.

8. Activities should enable students to understand how a text is constructed.

9. Activities should enable students to understand cultural context and cultural differences.

10. Activities should enable students to develop social awareness.

11. Activities should be as authentic as possible.

12. Activities should vary the roles and groupings.

13. Activities should be of various types and purposes

14. Activities should use authentic texts or realia when possible.

15. Activities should employ a variety of materials.

Teaching through interactive activities, Savignon in Hinkle (2005:637) explains: "A collection of role plays, games, and other communicative activities can involve learners in the experience of communication. Teacher can provide learners with the equivalent expressions that would help them to participate in the negotiation of meaning". The interactive classroom activities for communicative language teaching implies new roles in classroom for teachers and learners. Learners had to participate in classroom activities based on a cooperative rather than individualistic approach to learning. Students had to become comfortable to listen to their peers in group work or pair work tasks, rather than rely on the teacher as a model. They were expected to have a greater resposibility for their own learning. And the teachers had to assume the role of facilitator and monitor. Rather than being a model for correct speech and writing and one with the primary responsibility of making students produce a lot of error-free sentences, the teacher had to develop a different view of learners' errors and of his/her own role in facilitating language learning (Richards. 2006). 


\section{A Model of Communicative Teaching and Learning of English Vocabulary through Interactive Activities}

Before conducting a process of teaching and learning in the classroom, a teacher should prepare a model of teaching designed based on the curriculum framework and the principles of learning and teaching to guide learning, teaching and assessment for students to achieve the outcomes. The teaching and learning model is a guide to teach students the techniques of creative and productive thinking.

A teaching model deals with the ways in which learning environments and instructional experiences can be constructed, sequenced, or delivered. It may provide theoretical or instructional frameworks, patterns, or examples for any number of educational components - curricula, teaching techniques, instructional groupings, classroom management plans, content development, sequencing, delivery, the development of support materials, presentation methods, etc. Teaching models may even be discipline or student-population specific.

A model of teaching and learning is a critical instructional planning and delivery to help educators:1) develop highly tuned and more varied professional repertoires;2) allow them to reach larger numbers for students more effectively;3) create either more uniform, or varied, or effective instructional events, guided by targeted subjects, content, or processes; 4) understand curricular better, especially as different models can be matched specifically both learning outcomes and/or targeted learning populations;5) gain needed insights into why some methods work with some learners. while others do not;6) radically modify or redesign existing methods of teaching and instructional delivery so that emerging or modified instructional techniques may better meet the needs of tomorrow's students.

As mentioned previously, the purpose of teaching English as a foreign language is able to increase the communicative competence, either in spokenand written. In improving communicative competence, teachers not only provide a variety of knowledge about the language (grammatical competence), the teacher should also provide the ability to communicate (communicative competence) practically in developing the English skills of students. Communicative approach is appropriate in teaching English to train communicative competence. By using communicative approach, the learners can ultimately capture the entire communication without analyzing language into units of grammatical or linguistic elements such as sentence patterns, vocabulary, and so on.

Classroom is a place where the interaction between teacher and students happen. Teaching vocabulary communicatively can be effetive by using interactive activities in the classroom. The teacher can be a facilitator and monitor, while the students can be active in learning vocabulary through games interactively. Through interactive activities, a teacher must consider that the students have to actually use the new words and they also must understand the new word's meaning, and then they must practice in using it. The teacher can use pictures, explain the word's usage, pronunciation and spelling. 
A Model of Communicative Teaching and Learning of English Vocabulary through Interactive Activities hopefully can give opportunities for the students to be active more in the classroom and finally can improve their mastery of vocabulary.

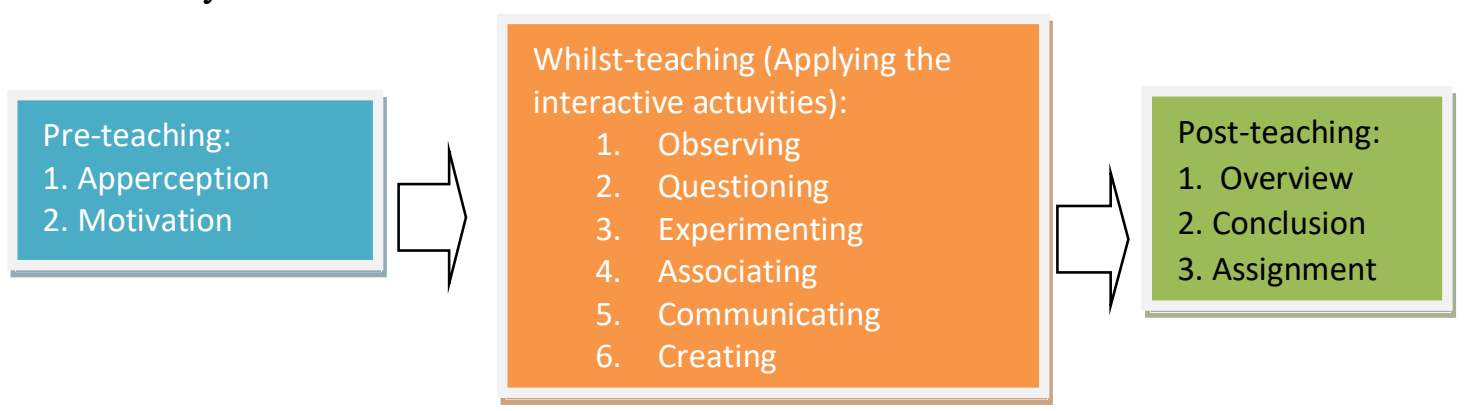

Figure 1. The Steps of Teaching English Vocabulary

An Example of A Model of Communicative Teaching and Learning of English Vocabulary through Interactive Activities

Materials/Topic : I Love People around Me

Teaching Method : Scientific Learning Approach

A. Pre-teaching:

1. Greeting

2. Checking the attendance list

3. Checking the students' readiness

4. Giving the students motivation contextually related to the teaching materials and everyday life, by giving examples.

5. Asking about the relation between students' prior knowledge and the material learned.

6. Explaining the purpose of learning or basic competencies to achieve.

B. Whilst-teaching: (Applying interactive activities)

1. Observing:

a. The students observe the image of "family tree" shown by the teacher.

b. The students listen to the teacher explaining about the image of "family tree".

c. The students complete the identity format based on information obtained from the image of "family tree" that has been described.

2. Questioning:

With the guidance and direction of the teacher, the students ask questions about the pictures of "family tree", as well as other things that they want to know.

3. Exploring/Experimenting:

a. The class is devided into groups of four. 
b. The Students receive a distribution of tasks from teachers containing a vocabulary of "family" in English and Indonesian differently for each group. (Matching Game)

c. The students find the appropriate vocabulary words from English to Indonesian contained in the text in groups.

4. Associating:

With the help of the media showedbythe teacher, the students identify the results of the group discussion.

5. Communicating:

a. Two of the students (representative of the group) come forward trying to use the media to describe the materials

b. The teacher gives feedback about concept of the materials being studied.

\section{Creating:}

The teacher gives guided, semi guided, or free productions tasks to the studdents to creat a text.

C. Post-teaching:

1. The students and teacher reflect on the learning activities.

2. The students and teacher provide feedback on the process and learning outcomes.

3. The teacher and students make a summary of the materials that has been studied.

4. The teacher gives information about the plan of learning activities for the next meeting.

\section{CONCLUSION}

English as an international language is a foreign language taught for the students in Indonesia. Teaching English generally aims to give communicative competence for the students. Vocabulary as a component of language teaching plays an important role in improving communicative competence of the students.

Before conducting the process of teaching and learning in the classroom, an English teacher must prepare a model of teaching. A model of teaching is designed based on the framework of curriculum and the principles of learning and teaching to guide learning, teaching and assessment for students to achieve the outcomes.

In designing a model of teaching and learning of English vocabulary through interactive activities, hopefully an English teacher can make the students enjoyable and interested in studying English. The teacher must be also creative in using some appropriate approaches, techniques, and games in the process of teaching and learning in applying interactive activities. 


\section{REFERENCE}

Brown, H.D. (2000). Principles of language learning and teaching. New York: Longman Inc.

Brown, H.D. (2007). Teaching by principles: An Interactive approach to language pedagogy. New York : Longman Inc.

Cook, Vivian. Teaching english as a foreign language. In Hinkel, Eli. (2011). Handbook of research in second language teaching and learning. Volume II. London: Roudledge.

Finnochiaro, David. (1974). Language teaching methodology. London: Prentice Hall Publishing.

Grave, Kathleen. (2000). Designing language courses A guide for teachers. Canada: Heinle and Heinle Publishers.

Littlewood, W. (1981). Communicative language teaching: An introduction. Cambridge: Cambridge University Press.

Madya, Suwarsih. (2013). Metodologi pengajaran bahasa: dari era prametode sampai era pascametode. Yogyakarta: UNY Press.

McCarten, Jeanne. (2007). Teaching vocabulary: lessons from the corpus, lessons for the classroom. New York: Cambridge University Press.

McCarthy, Michael. (1990). Language Teaching, A Scheme for teacher education. New York: Oxford University Press.

Nation, I.S.P. (2001). Learning vocabulary in another language. The United Kingdom: Cambridge University Press.

Nation, I.S.P. Teaching and learning vocabulary. In Hinkel, Eli. (2005). Handbook of research in second language teaching and learning. London: Lawrence Erbaum Associates Publishres.

Richards, J.C. and Renandya,W.A. (2002). Methodology language teaching: an anthology practice. New York: Cambridge University Press.

Richards, J.C. (2006). Communicative language teaching today. New York: Cambridge University Press.

Tomlinson, Brian and Hitomi Masuhara. (2004). Developing language course materials. Singapore: SEAMEO Regional Language Centre. 
Thornbury, Scott. (2002). How to teach vocabulary. Malaysia: Pearson Education Limited.

Wright, Sue. (2004). Language Policy and Language Planning: from Nationalism to Globalization. New York: Palgrave Macmillan. 